\title{
AP4S1 splice-site mutation in a case of spastic paraplegia type 52 with polymicrogyria
}

Susana Carmona, PhD, Clara Marecos, MD, Marta Amorim, MD, Ana C. Ferreira, MD, Carla Conceição, MD, José Brás, PhD, Sofia T. Duarte, MD, PhD,* and Rita Guerreiro, PhD*

Neurol Genet 2018;4:e273. doi:10.1212/NXG.0000000000000273
Correspondence

Dr. Guerreiro

r.guerreiro@ucl.ac.uk

Hereditary spastic paraplegias (HSPs) are a group of rare inherited neurodegenerative disorders that result from primary retrograde dysfunction of the long descending fibers of the corticospinal tract, causing lower limb spasticity and muscular weakness. This group of diseases has a heterogeneous clinical presentation. An extensive list of associated genes, different inheritance patterns, and ages at onset have been reported in HSPs. ${ }^{1}$ Spastic paraplegia type 52 (SPG52) is an autosomal recessive disease caused by AP4S1 mutations. The disease is characterized by neonatal hypotonia that progresses to hypertonia and spasticity in early childhood, developmental delay, mental retardation, and poor or absent speech. Febrile or afebrile seizures may also occur. ${ }^{2-4}$

\section{Clinical case presentation}

We report the case of a Portuguese 2-year-old boy born to healthy nonconsanguineous parents after a full-term gestation with intrauterine growth restriction after week 37. During the first months of life, the patient presented poor weight gain, hyperammonemia with elevation of glutamine and ornithine, low citrulline, and negative orotic acid. Weight recovery and normalization of amino acid profile were observed after protein restriction and remained normal after reintroduction of normal diet. Genetic study of urea cycle disorders (NAGS, CPS, and OTC) was negative. Around 9 months of age, global developmental delay, hypotonia, and strabismus were evident. Brain MRI with spectroscopy (performed at 10 months) showed delayed myelination/hypomyelination associated with a posterior perisylvian polymicrogyria, thinning of the corpus callosum, dilation and dysmorphia of the ventricles, and enlargement of the subarachnoid frontotemporal space (figure A). Spectroscopy suggested a possible discrete reduction of $\mathrm{N}$-acetylaspartate. EEG showed a slight intermittent lentification in the left temporal region. At 15 months of age, the patient had 1 afebrile episode of status epilepticus. Two previous shorter episodes with fever had also occurred. Levetiracetam was started. No regression of psychomotor development after seizure was observed, and the patient has been evolving gradually with improvement of axial hypotonia. He says a few simple words, responds to his name, and has some nonverbal communication. The most recent neurologic evaluation revealed an alteration of the muscle tone (hypertonia) in the left lower limb and pyramidal signs in both legs.

Exome sequencing of the proband and parents was performed as described in Supplementary Material (links.lww.com/NXG/A86) and revealed the homozygous AP4S1 splice site NM_001128126.2:c.294+1G>T r.619_687del variant in the proband, present in the heterozygous state in the parents (figure B). The variant was located in a $2.4-\mathrm{Mb}$ homozygous region

\footnotetext{
*These authors contributed equally to the manuscript.
}

From the Department of Molecular Neuroscience (S.C., J.B., R.G.), UCL Institute of Neurology, University College London, United Kingdom; Paediatric Neurology Department (C.M., S.T.D.), Hospital Dona Estefânia, Centro Hospitalar de Lisboa Central; Genetics Department (M.A.), Hospital Dona Estefânia, Centro Hospitalar de Lisboa Central; Reference Center of Inherited Metabolic Diseases (A.C.F.), Centro Hospitalar de Lisboa Central; Neuroradiology Department (C.C.), Hospital Dona Estefânia, Centro Hospitalar de Lisboa Central, Lisbon, Portugal; UK Dementia Research Institute (J.B., R.G.), University College London, United Kingdom; and Department of Medical Sciences (J.B., R.G.), Institute of Biomedicine, iBiMED, University of Aveiro, Portugal.

Funding information and disclosures are provided at the end of the article. Full disclosure form information provided by the authors is available with the full text of this article at Neurology.org/NG.

The Article Processing charge was funded by the authors.

This is an open access article distributed under the terms of the Creative Commons Attribution-NonCommercial-NoDerivatives License 4.0 (CC BY-NC-ND), which permits downloading and sharing the work provided it is properly cited. The work cannot be changed in any way or used commercially without permission from the journal. 
A

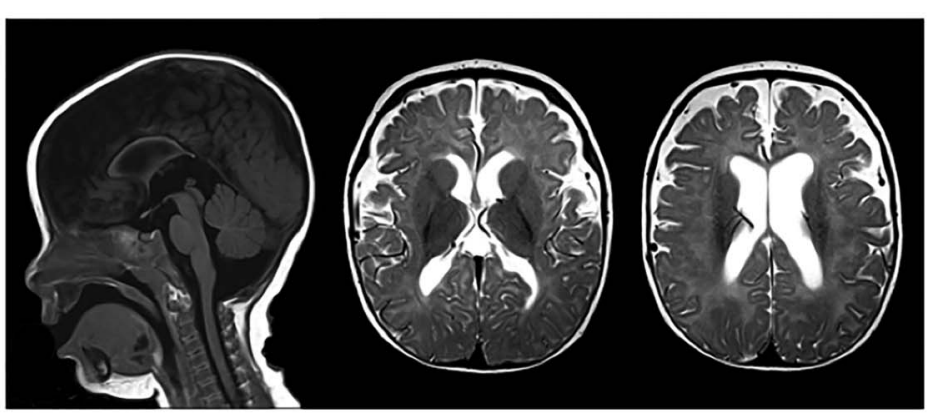

B

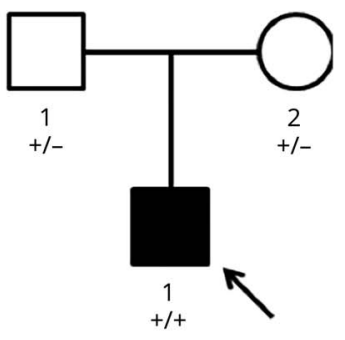

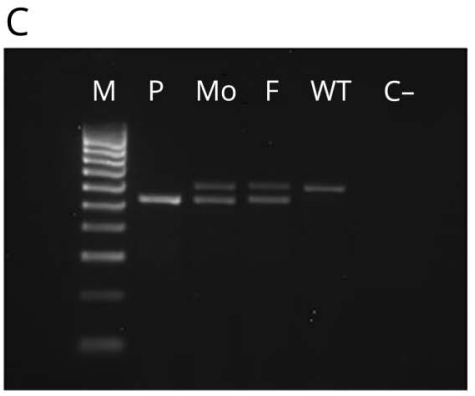

D

\begin{tabular}{|c|c|}
\hline WT & MIKFFLMVNKQGQTRLSKYYEHVDINKRTLLETEVIKSCLSRSNEQCSFIEYKDFKLIYR \\
\hline mut & $\begin{array}{l}\text { MIKFFUMVNKQGQTRLSKYYEHVDINKRTLLETEVIKSCLSRSNEOCSFIEYKDFKLIYR } \\
* * * * * * * * * * * * * * * * * * * * * * * * * * * * * * * * * * * * * * * * * * * * * * * * * * * * * * * * * * * * * * * * * *)\end{array}$ \\
\hline $\begin{array}{l}\text { WT } \\
\text { mut }\end{array}$ & 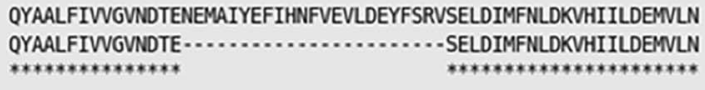 \\
\hline $\begin{array}{l}\text { NT } \\
\text { nut }\end{array}$ & $\begin{array}{l}\text { GCIVETNRARILAPLLILDKMSES } \\
\text { GCIVETNRARILAPLLILDKMSES } \\
* * * * * * * * * * * * * * * * * * * * *\end{array}$ \\
\hline
\end{tabular}

(A) Left image: sagittal T1 weighted image showing thin corpus callosum. Central and right images: axial T2 weighted images showing delayed myelination, bilateral posterior perisylvian polymicrogyria, dysmorphic and enlarged ventricles, and enlargement of subarachnoid space. (B) Family pedigree. The proband presents the splice-site variant chr14:g.31542180G>T NM_001128126.2:c.294+1G>T in the homozygous state, and both parents are heterozygous for the variant. +: c.294+1G>T allele; -: wild-type allele. (C) AP4S1 transcript size of the homozygous patient, both heterozygous parents, and the wild-type individual. A shorter transcript is produced in the presence of the variant. Each band of the marker ladder represents 100 bp (band size from gel bottom to top: $100,200,300,400,500,600,700,800,900$, and 1000 bp). (D) Alignment of the wild-type protein sequence (NP_001121598) to the mutated protein. The alignment was performed with Clustal Omega. The variant leads to the loss of amino acids $76-98$. $C-=$ negative control; $\mathrm{F}=$ father; $\mathrm{M}=\mathrm{marker}$ ladder; Mo = mother; mut = mutated protein; $\mathrm{P}=$ patient; $\mathrm{WT}=$ wild-type.

of chromosome 14. This variant is extremely rare in the population, with only 1 heterozygous individual present in the Genome Aggregation Database. In silico analysis predicted the loss of the donor splice site of exon 4. A transcript size analysis and Sanger sequencing of cDNA confirmed the presence of a shorter transcript skipping exon 4 associated with the variant (figure $\mathrm{C}$ ). As a consequence, the polypeptide of 23 amino acids (76 a.a.-98 a.a.) encoded by exon 4 is lost (figure D).

\section{Discussion}

AP4S1 encodes the small subunit of the adaptor protein complex-4 (AP4 complex). This complex is recruited to the trans-Golgi network, where it mediates vesicle trafficking to endosomes or basolateral plasma membrane in a clathrinindependent manner. ${ }^{5}$ Mutations in the 4 subunits of the complex have been associated with similar autosomal recessive phenotypes mainly characterized by spastic tetraplegia. ${ }^{6}$ The mutation found in our patient leads to the loss of exon 4, with predicted important consequences to the protein structure and the AP4 complex function. Anatomical changes similar to those observed in patients have been reported in an AP-4 complex knockout mouse model: enlargement of the lateral ventricles and thinning of the corpus callosum. ${ }^{7}$ Similar changes have also been seen in the patient described here, together with febrile and afebrile seizures. When exome sequencing was performed and analyzed, the patient did not show hypertonia in the lower limbs. However, as reported in other patients, this clinical entity may progress from hypotonic to hypertonic status. The most recent neurologic evaluation revealed the presence of hypertonia in the left leg, associated with pyramidal signs, suggesting the possibility of future development of a spastic paraparesis, typical of this disease.

Here, we report a case of SPG52 associated with posterior perisylvian polymicrogyria, unexplained transitory hyperammonemia, and absence of facial dysmorphisms, which suggest an expansion of the disease phenotype.

\section{Author contributions}

S. Carmona: study concept and design; acquisition, analysis and interpretation of data; and writing of the manuscript. C. Marecos, M. Amorim, A.C. Ferreira, and C. Conceição: acquisition of patient data and critical revision of the manuscript for intellectual content. J. Brás: study concept and design; analysis and interpretation of data; and critical revision of the manuscript for intellectual content. S.T. Duarte: 
acquisition of patient data; analysis and interpretation of data; and writing and critical revision of the manuscript for intellectual content. R. Guerreiro: study concept and design; analysis and interpretation of data; study supervision; and writing and critical revision of the manuscript for important intellectual content.

\section{Acknowledgment}

The authors acknowledge the family who participated in this study.

\section{Study funding}

This work was partially funded by the Alzheimer's Society.

\section{Disclosure}

S. Carmona, C. Marecos, M. Amorim, A.C. Ferreira, and C. Conceição report no disclosures. J. Brás serves on the editorial board of the Journal of Parkinson's Disease and has received research support from the Alzheimer's Society. S. Temudo Duarte has received travel funding from Nutricia. R. Guerreiro serves on the editorial boards of ScienceMatters, the American Journal of Neurodegenerative Disease, and the
Journal of Parkinson's Disease and has received research support from the Alzheimer's Society. Full disclosure form information provided by the authors is available with the full text of this article at Neurology.org/NG.

Received February 20, 2018. Accepted in final form July 31, 2018.

\section{References}

1. de Souza PVS, de Rezende Pinto WBV, de Rezende Batistella GN, Bortholin T, Oliveira ASB. Hereditary spastic paraplegia: clinical and genetic hallmarks. Cerebellum 2017;16:525-551.

2. Abou Jamra R, Philippe O, Raas-Rothschild A, et al. Adaptor protein complex 4 deficiency causes severe autosomal-recessive intellectual disability, progressive spastic paraplegia, shy character, and short stature. Am J Hum Genet 2011;88:788-795.

3. Hardies K, May P, Djémié T, et al. Recessive loss-of-function mutations in AP4S1 cause mild fever-sensitive seizures, developmental delay and spastic paraplegia through loss of AP-4 complex assembly. Hum Mol Genet 2015;24:2218-2227.

4. Tessa A, Battini R, Rubegni A, et al. Identification of mutations in AP4S1/SPG52 through next generation sequencing in three families. Eur J Neurol 2016;23:1580-1587.

5. Park SY, Guo X. Adaptor protein complexes and intracellular transport. Biosci Rep 2014;34:e00123.

6. Tüysüz B, Bilguvar K, Koçer N, et al. Autosomal recessive spastic tetraplegia caused by AP4M1 and AP4B1 gene mutation: expansion of the facial and neuroimaging features. Am J Med Genet A 2014;164A:1677-1685.

7. Ivankovic D, López-Doménech G, Drew J, Tooze SA. AP-4 Mediated ATG9A Sorting Underlies Axonal and Autophagosome Biogenesis Defects in a Mouse Model of AP-4 Deficiency Syndrome. bioRxiv. Epub 2017. Available at: biorxiv.org/content/early/ 2017/12/16/235101.abstract. Accessed January 31, 2018. 


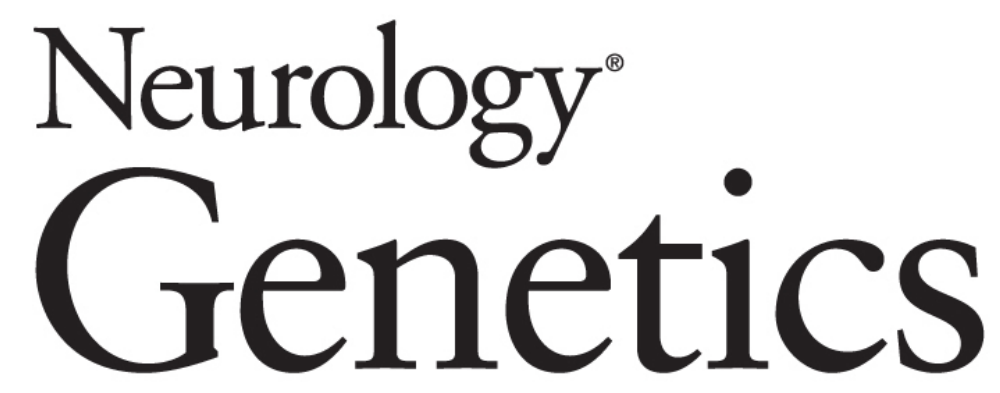

\section{AP4S1 splice-site mutation in a case of spastic paraplegia type 52 with polymicrogyria}

Susana Carmona, Clara Marecos, Marta Amorim, et al. Neurol Genet 2018;4;

DOI 10.1212/NXG.0000000000000273

This information is current as of September 19, 2018
Updated Information \&
Services
including high resolution figures, can be found at:
http://ng.neurology.org/content/4/5/e273.full.html
References
This article cites 6 articles, 1 of which you can access for free at: http://ng.neurology.org/content/4/5/e273.full.html\#\#ref-list-1
Citations
This article has been cited by 1 HighWire-hosted articles: http://ng.neurology.org/content/4/5/e273.full.html\#\#otherarticles
Subspecialty Collections
This article, along with others on similar topics, appears in the following collection(s):
Developmental disorders
http://ng.neurology.org//cgi/collection/developmental_disorders
Permissions \& Licensing
Information about reproducing this article in parts (figures,tables) or in its entirety can be found online at:
http://ng.neurology.org/misc/about.xhtml\#permissions
Reprints
Information about ordering reprints can be found online: http://ng.neurology.org/misc/addir.xhtml\#reprintsus

Neurol Genet is an official journal of the American Academy of Neurology. Published since April 2015, it is an open-access, online-only, continuous publication journal. Copyright Copyright $\odot 2018$ The Author(s). Published by Wolters Kluwer Health, Inc. on behalf of the American Academy of Neurology.. All rights reserved. Online ISSN: 2376-7839.

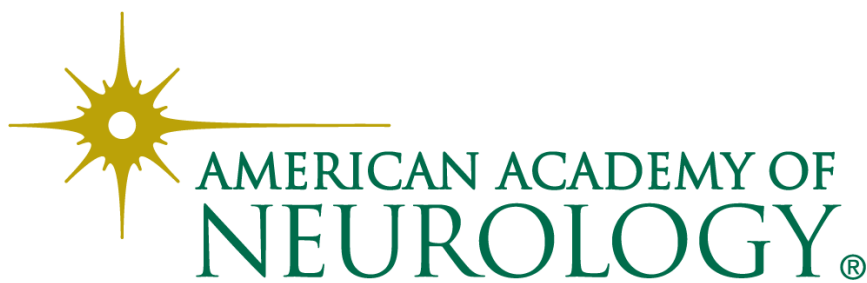

